\title{
British Dental Association
}

(the "Company")

(Registered in England and Wales with company number 00014161)

\section{Notice of Extraordinary General Meeting}

NOTICE IS HEREBY GIVEN that an Extraordinary General Meeting of the Company will be held at 9am on Saturday 4 February 2012 at 64 Wimpole Street London W1G 8YS to consider, and, if thought fit, to pass the following resolution, which will be proposed as a special resolution:

\section{SPECIAL RESOLUTION}

THAT the Articles of Association contained in document annexed hereto be approved and adopted as the new Articles of Association of the Company with immediate effect in substitution for and to the entire exclusion of all existing Articles of Association of the Company.

Dated 10 December 2011

BY ORDER OF THE REPRESENTATIVE BODY

Registered Office:

64 Wimpole Street

London, W1G 8 YS

NOTE: A Member entitled to attend and vote at the Meeting is entitled to appoint a proxy who need not be a Member to attend and on a poll to vote instead of him.

DOI: $10.1038 /$ sj.bdj.2011.1050 


\section{Memorandum of Association of the British Dental Association Memorandum}

1. The name of the Association is the "British Dental Association".

2. The registered office of the Association is to be in England.

3. The objects for which the Association is established are:

(1) The promotion of Dental and the allied sciences, and the maintenance of the honour and the interests of the Dental Profession (which expression in this Memorandum includes every branch of the Dental Profession).

(2) To encourage and promote the improvement of the health, and particularly the dental health, of the public.

(3) To encourage and promote the study of Dentistry and its allied sciences and with a view thereto to provide for the delivery of lectures and the holding of classes, study circles and other similar projects and to establish scholarships, grants, rewards and other benefactions, and for such purpose to grant or lend such sums of money on such terms out of the funds of the Association to such individuals, associations or institutions, incorporated or not incorporated, with objects similar to those of the Association, as may from time to time be determined.

(4) To maintain the spirit and provisions of the Dentists Act 1984 and any statutory modification or re-enactment thereof by such lawful means as may be necessary and to promote excellence and just and honourable practice in the conduct of the profession.

(5) To promote hold and encourage the promotion and holding of meetings of members of the Association and of the Dental Profession generally throughout the world.

(6) To diffuse amongst its members information on all matters affecting the Dental Profession and to print, publish, issue and circulate such papers, periodicals, books, circulars and other literary undertakings as may seem conducive to any of these objects.

(7) To establish, form and maintain a library and collection or museum of instruments, equipment, models, designs, drawings, and other articles of interest in connection with the Dental Profession.

(8) To give the legislature and public bodies and others facilities of conferring with and ascertaining the views of persons engaged in the Dental Profession as regards matters directly or indirectly affecting that profession.

(9) To originate and promote improvements in the law affecting the Dental Profession and to support or oppose alterations therein, and to effect improvements in administration, and for the purposes aforesaid to petition Parliament and take such other steps and proceedings as may be deemed expedient.

(10) To represent the Dental Profession in its relations and negotiations and to confer with Departments of State, bodies set up by Departments of State, local and other public authorities, bodies or persons in regard to all matters affecting the Dental Profession and generally to watch over and protect the interests of persons engaged in that profession.

(11) To establish, subsidise, promote, co-operate with, receive into union, become a member of, act as or appoint trustees, agents or delegates for, control, superintend, lend monetary assistance to or otherwise assist any associations or institutions incorporated or not incorporated, with objects altogether or in part similar to those of the Association and the application of whose income and property is restricted in the same manner as is the application of the income and property of the Association under the provisions of this Memorandum of Association. 
(12) To establish, undertake, superintend, administer and contribute to any charitable or benevolent fund from whence may be made donations or advances to deserving persons who are or have been engaged in the Dental Profession or the dependants or connections of any such persons; and to contribute or otherwise assist any charitable or benevolent institution or undertaking.

(13) To establish and support or aid in the establishment and support of association funds trusts and schemes calculated to benefit employees or ex-employees of the Association or of any association received into union with the Association or the dependants or connections of any such employee or ex-employee and to pay pensions, annuities or gratuities to any such person.

(14) To admit any persons (whether eligible or not eligible for membership) to be affiliate or honorary members of the Association on such terms and to confer on them such rights and privileges as may seem expedient.

(15) To undertake and execute any trusts which may seem to the Association conducive to any of its objects.

(16) To purchase, take, lease, exchange, hire or otherwise acquire any real or personal property or any rights or privileges necessary or convenient for the purposes of the Association, and to construct, alter and maintain any buildings required for the purposes of the Association.

(17) To sell, improve, manage, develop, lease, mortgage, dispose of, turn to account, or otherwise deal with all or any part of the property of the Association.

(18) To borrow any moneys required for the purposes of the Association upon such terms and on such scrutinies as may be determined.

(19) To invest the moneys of the Association not immediately required upon such securities or otherwise in such manner as may from time to time be determined.

(20) To do all such other lawful things as are incidental or conducive to the attainment of the above objects or any of them.

4. The income and property of the Association, from whatever source derived shall be applied solely towards the promotion of the objects of the Association, as set forth in this Memorandum of Association, and no portion thereof shall be paid or transferred, directly or indirectly, by way of dividend or bonus, or otherwise however, by way of profit to the Members of the Association. Provided that nothing herein shall prevent the payment in good faith of remuneration to any officers or servants of the Association, or to any Member of the Association, or other person, in return for any services actually rendered to the Association.

5. The fourth paragraph of this Memorandum is a condition on which a licence is granted by the Board of Trade to the Association, in pursuance of Section 23 of the Companies Act 1867.

6. If any Member of the Association pays or receives any dividend, bonus, or other profit, in contravention of the terms of the fourth paragraph of this Memorandum, his liability shall be unlimited.

7. Every Member of the Association undertakes to contribute to the assets of the Association in the event of the same being wound up during the time that he is a Member, or within one year afterwards, for payments of the debts and liabilities of the Association contracted before the time at which he ceases to be a Member, and the costs, charges and expenses of winding up the same, and for the adjustment of the rights of the contributors amongst themselves, such amount as may be required, not exceeding the sum of one pound and five pence, or in case of his liability becoming unlimited, such other amount as may be required, in pursuance of the last preceding paragraph of this Memorandum.

8. If upon the winding up or dissolution of the Association there remains, after the satisfaction of all its debts and liabilities, any property whatsoever, the same shall not be paid to or distributed among the Members of the Association, but shall be given or transferred to some other institution or institutions having objects similar to the objects of the Association, to be determined by the Members of the Association at or before the time of dissolution, or in default thereof such property shall be given to some charitable object.

9. We, the several persons whose names and addresses are subscribed to this Memorandum are desirous of being formed into an Association, in pursuance of this Memorandum of the Association. 
EGM NOTICE

NAMES, ADDRESSES AND DESCRIPTIONS OF SUBSCRIBERS

Names

George Augustus Ibbitson

Thomas Arnold Rogers

Edwin Saunders

Thomas Underwood

James Parkinson

James Smith Turner

Witness of above signatures,

Dated 28th May 1880

John Tomes

Witness of above signature,
Addresses

19a Hanover Square, W

23 Endsleigh Street, WC

13a George Street, Hanover Square, W

11 Bedford Square, WC

36 Sackville Street

12 George Street, Hanover Square,

John Frederick Bowman

21 Bedford Row,

London WC

(Solicitor)

Upwood Grove, Caterham, Surrey

John Stowar MD

113 Ladbroke Grove, London, W.
Descriptions

FRCS Eng

MRCS Eng

FRCS Eng

LDS Eng

LDS Eng

MRCS LDS Eng 


\section{Articles}

The Companies Acts, 1862 to 1985

Company limited by guarantee and not having a share capital

\section{Articles of Association of the British Dental Association Preliminary}

1. In these presents, including the By-laws set forth in the Schedule hereto, unless there be something in the subject or context inconsistent therewith, the words and expressions following shall have the meanings hereinafter assigned to them respectively:

"Articles" means the regulations contained in these Articles with such (if any) modifications as may from time to time be made therein.

"The Association" means the British Dental Association.

"Branch" and "Section" mean respectively a Branch and Section constituted as hereinafter provided.

"The By-laws" means the By-laws of the Association for the time being in force, and made available by the Principal Executive Committee on the Association's website.

The "Chief Executive" means the officer employed to oversee the day to day running of the BDA.

“The Dentists Acts" means the Dentists Act 1984 or any modification or re-enactment thereof for the time being in force.

“The Dentists Register” means the Dentists Register kept pursuant to the Dentists Acts.

“Existing” means existing at the time when these Articles came into operation.

“Extraordinary General Meeting” has the meaning assigned to it by Article 63.

"Extraordinary resolution" means a resolution passed by the same majority as is required to pass a Special Resolution at a general meeting of which not less than 21 days' notice, specifying the intention to propose the resolution as an extraordinary resolution, has been duly given.

“”Directors means the senior staff who are appointed at the Director grade.

“The Honorary Officers" means those officers provided for by Article 26.

“The Journal" means the Journal to be published as thereinafter provided.

"Presidential Meeting" means the meeting of the Association at which the President is installed.

"Present" includes, where the word describes the attendance of a person at a meeting, the participation of such a person upon the request of the Chair of the meeting by means of a teleconferencing or video conferencing link provided that in the case of any proceedings held in accordance with the provisions of Article 17 the word present shall require the physical presence of such a person the relevant meeting.

"Professional Group" means a Professional Group constituted as hereinafter provided.

"Primary Postal Address" means the address indicated by a member as either their principal residence or 
their principal place of work. Each member shall be required to choose one of these as their geographic locator within the United Kingdom for the purposes of candidacy and election.

“The Principal Executive Committee means the Principal Executive Committee hereinafter mentioned.

"The Seal" means the Common Seal of the Association.

"Standing Committee" means a standing committee of the Principal Executive Committee as provided for by these Articles.

"The Statutes" means The Companies Acts 1862-1985 and any modification or re-enactment thereof for the time being in force.

"The United Kingdom” means Great Britain and Northern Ireland and the Isle of Man and the Channel Islands.

"Working Group" means a Working Group of the Principal Executive Committee constituted as hereinafter provided.

"Year" refers to a calendar year.

Words and expressions defined in the statutes shall have the same meanings in these Articles.

Words importing the singular number include the plural and vice versa.

Words importing the masculine gender include the feminine gender.

Marginal Notes

The marginal notes are for reference only and shall not affect the construction of these Articles.

\section{MEMBERSHIP}

Number of Members

Membership
2. The number of Members of the Association is unlimited.

3. Membership of the Association shall be:

(A) Ordinary Membership (that is to say membership which is not special membership) and

(B) Special Membership which shall be of the following categories:

(1) Honorary Membership

(2) Life Membership

(3) Distinguished Membership

(4) Temporary Membership

(5) Affiliate Membership

(6) Student Membership

(7) Any other class of member as may be determined from time to time by the Representative Body

The Ordinary Members of the Association shall be entitled to the rights and privileges and shall be subject to the restrictions set forth in these Articles, and the members of the Association who are members of any of the categories of special membership shall be entitled to such of the said rights and privileges and 
shall be subject to such additional restrictions as are set forth in these Articles and are applicable to the category of special membership to which they belong.

Present Members

4. The existing members of the Association shall be deemed to consist of all the persons who shall be admitted as members, in such manner and upon such conditions as may from time to time be prescribed by or pursuant to these Articles.

Duration of Membership 5. Every member shall remain a member until he ceases to be a member in accordance with the provisions of these Articles.

Right of Membership $\quad 6$. The rights of Members are personal and shall not be transferable or transmissible.

Qualifications for Ordinary Membership
7. (A) Any person who fulfils the following qualifications shall be eligible as an Ordinary Member of the Association, that is to say, any person who, whether he is actually practising dentistry or not:

(1) is of good character, and

(2) is a person registered in the Dentists Register or who is or has been legally entitled to be so registered and who is not disqualified by these Articles.

Provided that his name has not been erased or suspended from the Dentists Register by order of the Professional Conduct Committee of the General Dental Council or from the Medical Register by order of the Professional Conduct Committee of the General Medical Council and that suspension or interim suspension by order of the Preliminary Proceedings Committees or the Health Committees of these Councils do not disqualify a person under Article 7(A)(2) above.

(B) Every application for membership of the Association shall contain an undertaking by the applicant that, on admission to membership and if the case may be on transfer from one category of membership to another, he will abide by the Articles and By-laws of the Association for the time being and from time to time in force and also the Rules of such Branch, Section or Professional Group (if any) as he may from time to time belong to, and an undertaking to pay his subscription as it is due.

Right to refuse

Election
8. (A) The Principal Executive Committee may refuse a candidate for membership of the Association.

(B) Except as otherwise provided in these Articles, the requirements of membership shall from time to time be determined by or in accordance with the By-laws.

\section{HONOURS AND AWARDS OF THE ASSOCIATION}

(A) Presidency

TheThe Annual General Meeting shall each year upon the nomination of the Principal Executive Committee elect a President of the Association in accordance with the provisions of Article 27 (A)

(B) Honorary Membership

(1) Members of the Dental profession and of scientific eminence, or persons distinguished in medical or allied sciences, or persons who may have rendered distinguished service to the Association, or to the promotion of dental and any allied sciences, or who, upon the recommendation of the Honours and Awards Committee, will further or advance the interests of the Association, may be elected Honorary Members by the Principal Executive Committee .

(2) An Honorary Member shall have none of the liabilities of Members as regards subscriptions and 
shall not be entitled to any vote, but shall have the privilege of attending the Annual General Meeting in each year and such other privileges as may be conferred upon him by the Articles. Provided that any person who is eligible for ordinary membership of the Association pursuant to Article 7 and who is elected an Honorary Member shall have all the rights and privileges of ordinary membership.

(C) Fellowship

(1) Any Ordinary Member (including a Life Member) of the Association who has:

(a) been for twenty years continuously an Ordinary Member of the Association, and

(b) in the opinion of the Principal Executive Committee upon the recommendation of the Honours and Awards Committee rendered outstanding and distinguished service to the dental profession and to the Association shall be eligible for election by the Principal Executive Committee as a Fellow of the Association.

(2) A Fellow of the Association shall have none of the liabilities of Members as regards subscriptions but shall have all the rights and privileges of ordinary membership of the Association and shall be eligible to be elected or appointed to any office in the Association.

(3) A Roll of Fellows shall be established and there shall not at any one time be more than forty Fellows of the Association.

(4) Upon admission to the Roll, a Fellow shall be presented to the Members of the Association in General Meeting or other occasion determined by the Principal Executive Committee, and shall receive a scroll, signed by the Officers of the Association, and a Badge of Fellowship, which he shall be entitled to wear at all General Meetings of the Association and at any Branch meeting which he attends.

(D) Life Membership

Any Ordinary Member of the Association who either:

(1) has been for twenty-five years continuously an Ordinary member of the Association, or

(2) has been (i) for ten years continuously an Ordinary Member of the Association and (ii) has ceased to practise Dentistry, and (iii) holds no paid dental appointment, shall be eligible for election by the Principal Executive Committee on recommendation by the Honours and Awards Committee as a Life Member of the Association. A Life Member shall have all the rights and privileges of membeship, but shall not be liable to pay any subscriptions to the Association or to any Branch thereof. A Life Member shall be eligible to be elected or appointed to any office in the Association. The honour is marked by the presentation of a scroll at a General Meeting or other occasion determined by the Principal Executive Committee

(E) Distinguished Member

Any Ordinary Member of the Association who has

(1) served in an outstanding capacity in the governing of the BDA

(2) given numerous years of service and significant contribution across BDA Committees

(3) given personal commitment to the running and welfare of the organisation

shall be eligible for election by the Principal Executive Committee on recommendation by the Honours and Awards Committee as a Distinguished Member of the Association. A Distinguished Member shall 
have all the rights and privileges of membership, but shall not be liable to pay any subscriptions to the Association or to any Branch thereof. The honour is marked by the presentation of a scroll at a General Meeting or other occasion determined by the Principal Executive Committee.

(1) The Association may honour any person (whether or not he be otherwise eligible for ordinary membership of the Association) who has given outstanding services to the Dental Profession or to the Association by awarding that person a John Tomes Medal of the Association.

(2) The Medal shall be awarded on the recommendation of the Honours and Awards Committee and agreement by the Principal Executive Committee of the Association. The medal shall be presented to the recipient with an appropriate scroll at a General Meeting of Members or other occasion determined by the Principal Executive Committee.

(3) A recipient of the Medal who is a dentist shall have all the rights and privileges of membership, but shall not be liable to pay any subscriptions to the Association or to any Branch thereof. This benefit, restricted to dentists, shall apply from $9^{\text {th }}$ October 2010 for all holders of the medal

(G) An entry on the Roll of Distinction

Upon the recommendation of the Honours and Awards Committee the honour of an entry of a persons name on the Roll of Distinction may be awarded by the Principal Executive Committee. The honour is defined in terms that the Association may honour any person, whether or not eligible for membership of the Association, for outstanding services to UK dentistry by entering that person on the Roll of Distinction. The honour is marked by the presentation of a certificate and a medal at a Presidential Meeting or other occasion determined by the Principal Executive Committee. Any dentist so honoured shall have all the rights and privileges of membership, but shall not be liable to pay any subscriptions to the Association or Branch thereof. This benefit shall apply from $9^{\text {th }}$ October 2010 for all dentists entered on the Roll of Distinction.

\section{(H) Certificate of merit for Services to the Association}

This shall be awarded to recognise any special service at any level of dentistry within the country. The certificate shall be awarded to mark contribution to a BDA Committee, commission, task force, project or event over a period of years, and assistance in the promotion of the BDA. The honour is marked by presentation of a certificate at a Presidential Meeting or other occasion determined by the Principal Executive Committee.

\section{(I) Certificate of Merit for Services to the Dental Profession}

This shall be awarded to recognise any special service at any level of dentistry either nationally or internationally and it is expected that this would be reserved for dentists or other persons who have contributed to academic or other work in furthering the profession, or individuals active in promoting advancements within the dental profession. The honour is marked by presentation of a certificate at a Presidential Meeting or other occasion determined by the Principal Executive Committee.

\section{TEMPORARY MEMBERSHIP}

Temporary Membership 10.(A) Any member of any Dental Association which is approved for the purpose by the Principal Executive Committee who is temporarily but not ordinarily resident in the United Kingdom may, on application in writing to the Chief Executive and on producing a recommendation from such an approved Association (but subject always to discretion of the Principal Executive Committee ) become a Temporary Member of the Association for the period of his temporary residence, not to exceed six months, but such period may be extended by the Principal Executive Committee on written application.

(B) A Temporary Member shall be liable to pay such subscription to the Association as shall from time 
to time have been determined, but shall not be entitled to any vote. He shall be entitled during his temporary membership of the Association to the following privileges:

(1) Attendance at Meetings of the Association.

(2) Use of the Members' rooms of the Association, including the reference facilities but not the lending facilities of the library

(3) To receive the Journal, subject to the sufficiency of supplies.

(4) Advice as to postgraduate education.

(5) Such other advice and assistance as the Association is reasonably able to offer.

\section{AFFILIATE MEMBERSHIP}

Affiliate Membership

11. The Principal executive Committee may admit any person (whether or not he be otherwise eligible for membership of the Association) to be an Affiliate Member of the Association and may from time to time prescribe:

(A) The conditions of eligibility of persons or classes of persons to become Affiliate Members.

(B) The mode and conditions of admission to membership.

(C) Their rights and privileges, and

(D) The rate or rates of subscription to be paid by them.

Provided always that:

(1) an Affiliate Member shall not be entitled to hold Office in or vote at any general meeting of the Association, or to hold office in, or vote at any meeting of a Branch or Section of the Association, or to vote in any elections of the Association and

(2) the subscription to be paid by an Affiliate Member shall be as determined from time to time by the Principal Executive Committee

(3) no person shall be admitted to be an Affiliate Member of the Association unless

(a) his admission is approved by special resolution of the Principal Executive Committee

(b) he meets the conditions of $11(\mathrm{~A})$ above

(4) no persons or classes of persons established as ancillary dental workers under the Dentists Act 1984, shall be eligible for Affiliate membership of the Association.

\section{STUDENT MEMBERSHIP}

Student Membership

Privileges of Student
12. (A) Any undergraduate student at a dental school who is ordinarily resident in the United Kingdom may, on application in writing to the Chief Executive and on payment of the prescribed subscription, be elected a Student Member of the Association.

(B) A Student Member shall be entitled to such privileges as are Members determined from time to time by the Principal Executive Committee

(C) A Student Member may be elected as a Subscribing Member of any Branch but shall not be reckoned as a Branch Member for the purposes of the Articles nor have a vote at any proceedings of such Branch. 
Termination of Student $\quad$ (D) A Student Member shall cease to be a Student Member of Membership Association upon admission to the Dentists Register when conditional on prior payment of the due subscription as a Student Member he shall (subject to By-law 3(B)) forthwith be deemed to have been elected a Member of the Association in accordance with By-law 3(A).

\section{SUBSCRIPTIONS}

Subscriptions

Payment of

Subscriptions

Privileges on Payment of Subscriptions
13. (A) The subscription payable by the Members of the Association shall be such a sum or sums as shall from time to time be determined by the Principal Executive Committee

(B) The Association may fix different rates of subscriptions for Ordinary Members and the respective categories of Special Membership and may also for different classes of members of the same category of membership or otherwise differentiate between members as to the Subscriptions payable by them as may be seen fit.

(C) Past Presidents of the Association and Vice-Presidents of the Association shall have none of the liabilities of Members as regards subscriptions.

14. (A) Subscriptions shall be paid when due, in such manner and to such officer of the Association or any Branch or Section thereof as the Representative Body may from time to time determine.

(B) The first year's subscriptions of a Member shall be paid on or immediately after his admittance to membership and shall cover the residue of the year then current. The subscription for the residue of that year shall be such proportion of the appropriate annual subscription as the Principal Executive Committee may from time to time determine.

15. (A) The subscription shall (subject to the restrictions contained in these Articles as respect Honorary, Temporary, Affiliate and Student Members) confer all the privileges of membership of the Association and the right to receive the publications of the Association issued to members during the period commencing with the date on which the subscription is received by the Association and terminating with the expiry of the period covered by the subscription.

(B) The subscription of an Ordinary Member of the Association shall entitle him to the ordinary privileges of membership of a Branch without further payment (subject to his compliance with the Regulations and By-laws affecting the Branch, and with the rules of the Branch, and with the conditions of and qualifications for membership of the Branch) and no other subscription (except voluntary subscriptions and except as provided in the By-laws) shall be demanded of or payable by any member of the Association.

(C) If a Member has failed to pay his subscription in the period determined by the Principal Executive Committee he shall be deemed to be in arrears in respect of his subscription until he pays the same or until the subscription period expires (whichever happens first) and so long as he is in arrears he shall have no voting rights.

\section{CESSER OF MEMBERSHIP OTHERWISE THAN BY EXPULSION}

Cesser of Membership otherwise

than by expulsion

16. A Member of the Association shall ipso facto cease to be a Member:

(A) On his death.

(B) If he fails to pay his subscription within such period as the Principal Executive Committee may from time to time determine.

(C) If, by notice in writing to the Chief Executive of the Association, he resigns from membership of the Association. Provided that, except with the consent of the Principal Executive Committee, a Member 
shall not have the right to resign from membership whilst any subscriptions or other moneys shall be owing from him to the Association.

(D) If his name is erased or suspended from the Dentists Register by order of the Fitness to Practise Panel of the General Dental Council or from the Medical Register by order of the Fitness to Practise Panel of the General Medical Council. However a member so suspended may make application to the Principal Executive Committee for Affiliate Membership during the suspension period.

(E) If (being an Honorary, Temporary, Affiliate or Student Member) he ceases from any cause whatsoever to be possessed of any qualification which was a condition precedent to his election as such a Member, or if he shall fail to conform to any of the conditions for the continuation of that membership.

\section{COMPULSORY TERMINATION OF MEMBERSHIP}

Expulsion on conviction 17. (A) If any Member shall be convicted in a Court of Justice in the United Kingdom of any offence punishable by imprisonment with or without option of a fine or if any such Member shall be convicted in a Court of Justice outside the United Kingdom of any offence which would, in the United Kingdom, be punishable as aforesaid the Ethics,Education and Standards Committee may if they think fit hold an enquiry into the nature and the circumstances of the case.

(B) Not less than twenty one days' notice shall be given to the Member implicated of the meeting at which the inquiry is to be held and of the substance thereof, and he shall be at liberty, if he so desires, to attend at the meeting for the purpose of explaining his conduct. The Ethics, Education and Standards Committee shall however be at liberty to proceed with the inquiry if the Member does not attend at the time and place appointed for the meeting.

(C) The Ethics, Education and Standards Committee shall not retry the case, but shall accept the conviction as being a proper conviction, and shall consider whether or not the offence is such as to render it undesirable that the Member shall continue to be a Member. The Committee may consider any extenuating circumstances put forward by the Member and like-wise any circumstances aggravating the offence.

(D) The Ethics,Education and Standards Committee shall report their finding to the Principal Executive Committee and may, if they think fit, recommend that the Member's membership should be terminated by expulsion or by his earlier resignation.

(E) The votes of not less than two thirds of the Ethics, Education and Standards Committee present at that meeting of the Committee or of six Members so present (whichever is the greater) shall be required for the purpose of exercising the power of recommending that membership should be terminated as aforesaid.

(F) The Principal Executive Committee shall not re-hear the case, but shall, if the Ethics,Education and Standards Committee have recommended that the Member's membership should be terminated, allow him to attend before them and to make any statement which the Principal Executive Committee may consider to be relevant. The Principal Executive Committee shall however be at liberty to proceed if the Member does not attend at the time and place appointed for the purpose.

(G) The Principal Executive Committee may decide that the Member should be expelled with or without the prior option of resignation. Such decision shall require the votes of not less than two thirds of the Members present and voting at that meeting of the Principal Executive Committee. Depending on the decision of the Principal Executive Committee the Member shall either be invited to resign within a specified period failing which he shall be expelled or he shall be expelled forthwith.

(H) In any inquiry held pursuant to paragraph (B) of this Article, and in any proceedings of the Principal Executive Committee pursuant to paragraph (F) of this Article, the Member (whether he is present or not) may be assisted in the presentation of his case by some other person provided that no practising Barrister or Solicitor shall be entitled to conduct the case for the Member. The procedure at any such inquiry or proceedings as aforesaid, shall, subject to this Article, be determined by the Chair of 
the meeting at which the inquiry is held or the proceedings take place, but the Member or the person assisting him shall be entitled to adduce information as to the character of the Member.

Expulsion following an inquiry
18. (A) Any Member whose conduct shall, upon inquiry by the Ethics, Education and Standards Committee, be deemed to be detrimental to the honour and interest of the dental profession, or calculated to bring the profession into disrepute, or to be prejudicial to the interests of the Association, may be expelled from membership in such manner as may be prescribed by these Articles.

(B) The Ethics, Education and Standards Committee may upon the representation of :

(1) The Principal Executive Committee or the Ethics, Education and Standards Committee, as regards any Member, whether he is a Member of a Branch or not, or

(2) The Council of any Branch as regards a Member who is a Member of that Branch, or

(3) Any ten or more Members as regards a Member who is not a Member of any Branch,

institute/initiate an inquiry into the conduct of such Member.

(C) Not less than twenty one days' written notice shall be given to the Member implicated of the meeting at which the inquiry is to be held and of the substance of the allegations made, and he shall be at liberty, if he so desires, to attend at the meeting for the purpose of explaining his conduct. The Ethics,Education and Standards Committee shall however be at liberty to proceed with the inquiry if the Member is absent for any reason whatsoever.

If at any such inquiry it is established that in relation to the facts alleged the Member has been found by the Professional Conduct Committee of the General Dental Council or the Professional Conduct Committee of the General Medical Council to be guilty of serious professional misconduct, the Ethics, Education and Standards Committee shall accept that finding as being a proper finding and shall without further inquiry find that the conduct of the Member is of the kind specified in paragraph (A) of this Article.

(E) At the meeting of the Ethics,Education and Standards Committee at which such inquiry is held any decision of the Committee which is adverse to the Member shall require the votes of not less than two thirds of the Members present at the meeting or of six Members, whichever is the greater.

(F) The Ethics, Education and Standards Committee shall report to the Principal Executive Committee after such inquiry:

(1) Their finding whether the conduct of the Member is of the kind specified in paragraph (A) of this Article and

(2) Their recommendation whether the Member's membership should be terminated by expulsion or by his earlier resignation.

(G) The Principal Executive Committee shall accept as conclusive the finding of the Ethics,Education and Standards Committee on the question whether the conduct of the Member is of the kind specified in paragraph (A) of this Article, but shall have full discretion to decide whether the Member's membership shall be terminated as aforesaid. If the Principal Executive Committee decides that the Member's membership shall be so terminated he shall thereupon cease to be a Member.

(H) A decision of the Principal Executive Committee to terminate the Member's membership shall require the votes of not less than two thirds of the members present and voting at that meeting of the Principal Executive Committee. Depending on the decision of the Principal Executive Committee the Member shall either be invited to resign within a specified period failing which he shall be expelled: or he shall be expelled forthwith. 
(I) The Principal Executive Committee shall, before deciding to take any action adverse to the Member, give him an opportunity to attend before them and to make any statement which the Principal Executive Committee may consider to be relevant. The Principal Executive Committee shall however be at liberty to proceed if the Member is absent for any reason whatsoever.

(J) In any inquiry held pursuant to paragraph (C) of this Article, the Member may be represented by any other person other than a practising Barrister or Solicitor.

(K) In any proceedings before the Principal Executive Committee pursuant to paragraph (I) of this Article the Member (whether he is present or not) may be assisted in the presentation of his case by some other person other than a practising Barrister or Solicitor. The procedure at any such inquiry or proceedings shall, subject to this Article, be determined by the Chair of the meeting at which the inquiry is held or the proceedings take place, but the Member or the person assisting him shall be entitled to adduce information as to the character of the Member.

\section{RE-ADMISSION TO MEMBERSHIP}

Re-admission to

membership
19. Any person who ceases to be a Member of the Association may be re-admitted to membership on such terms and subject to such conditions as may from time to time be determined by the Principal Executive Committee.

\section{BRANCHES, SECTIONS AND PROFESSIONAL GROUPS}

Branches

Membership of Branches

Sections

Membership of

Professional Groups

Branch and Section

Secretaries

Regulations of Branches

Sections and

Professional Groups
20. For the better attainment of the objects of the Association, Members thereof shall be formed into separate local bodies called "Branches". Sections may be formed within the areas of Branches. Members may also be formed into separate bodies called "Professional Groups".

21. A Branch shall comprise such body of Members as the Principal Executive Committee shall from time to time recognise and declare to be a Branch, and a Section shall be such body of Members belonging to any Branch as the Principal Executive Committee shall in like manner recognise and declare to be a Section of that Branch. Each Branch and each Section shall have a local area to be fixed from time to time by the Principal Executiev Committee. A Member who practises in one such local area but wishes to be a Member of a Branch constituted in relation to another local area (hereinafter called his "Branch of choice") may transfer his membership to his Branch of choice. He will thereafter enjoy voting rights in and privileges of membership of his Branch of choice only and shall be eligible to be elected or appointed to office only in relation to his Branch of choice. The membership by such a Member of a Section within his Branch of choice shall be determined by the Principal Executive Committee.

22. The Principal Executive Committee may from time to time declare or disband any body or number of Members whom they consider to be members of the dental profession in a particular sphere of practice or field of activity to be a Professional Group and may make such provisions as they deem expedient for the identification and recognition of any Professional Group.

23. Every Branch and Section shall elect and shall at all times have a secretary and shall procure that notice of every such election (including the address of the appointee) shall be given to the Secretary of the Association. Every Secretary of a Branch or Section shall be a Member of the Branch or Section which elects him.

24. Subject to the Articles of the Association, all Branches, Sections and Professional Groups shall be constituted, managed and governed and shall have such powers, rights and privileges, and shall be under such obligations as shall be prescribed by or in accordance with the By-laws. The By-laws may provide for contributions, grants and subscriptions out of the general funds of the Association to Branches, Sections 
and Professional Groups; and may impose on the Members of any Branch, Section or Professional Group such obligations towards the Association and the Branch, Section or Professional Group as may seem expedient; and may empower any Branch, Section or Professional Group to make any Rules in relation to the affairs thereof and to vary or repeal any such Rules; but the Rules of every Branch, Section or Professional Group shall be subject to the directions of the Principal Executive Committee and the Rules of every Section shall be approved by the Branch, to which it belongs. The Principal Executive Committee may at any time vary or repeal any Rules hereby authorised.

\section{THE JOURNAL}

British Dental Journal

Journal Contents

Other Publications

\section{HONORARY OFFICERS OF THE ASSOCIATION}

25. (A) A Journal, under the title of the British Dental Journal, shall be published as frequently as may be found to be expedient, by or on behalf of the Association.

(B) The Journal shall contain papers on dental science and practice and kindred topics, and shall, so far as expedient for the purposes of these Articles and for the giving of notice of Annual General Meetings and Extraordinary General Meetings of the Association be the primary medium of communications between the Association and the Members thereof.

(C) The Principal Executive Committee shall from time to time be entitled to arrange for the publication of such other periodicals and information as it may think desirable in such manner as it may think fit.

Honorary Officers

26. There shall be the following Honorary Officers of the Association, the Chair and Deputy Chair of the Principal Executive Committee, the Chairs of the English, Scottish, Welsh and Northern Ireland Councils, the Honorary Curator of the Museum and such other Honorary Officers as may from time to time be determined by the United Kingdom Council on the recommendation of the Principal Executive Committee. The Officers aforesaid shall hold office for such period as shall be determined from time to time by or in accordance with these Articles. All the Honorary Officers must be Members of the Association.

The President, President-Elect

and Immediate

Past President

27. (A) The President of the Association shall be nominated by the

Principal Executive Committee upon the recommendation of the Honours and Awards Committee and elected annually by the Annual General Meeting, and shall enter upon the duties of his/her office at a Presidential Meeting in the following year, and until then shall bear the title of President-Elect. At the expiration of his/her period of office, the Retiring President shall bear the title of Immediate Past President until the Presidential Meeting in the following year.

(B) the role and the responsibilities of the President shall be as follows:

- to act as the symbolic representative of the traditions, history and professional dignity of the Association

- to act as representative and ambassador of the policies, achievements, plans and aspirations of the Association to local branches, sections, groups and divisions

- to act as an informal conduit of grass roots communications to the senior representatives of the Association

- to use the dignity of the office of President to offer discreet and wise counsel to senior representatives as appropriate

- in liaison with senior elected representatives and staff, to plan a programme of events for the year, to cover, politically and professionally, all aspects of the Association's activities, both nationally and internationally 
- to represent the Association at the Presidential meetings and to deliver inaugural and valedictory addresses

- to represent the Association at the Annual British Dental Association Conference and Exhibition

- to represent the Association at official BDA receptions held in the course of the Presidential year

- to attend meetings of the United Kingdom Council and Principal Executive Committee as an observer, and such other committee meetings the President considers appropriate in the fulfilment of his/her role

- to attend external functions, including international functions, as invited or requested by the Chairs of the country councils and Chair of the Principal Executive Committee

Vice-Presidents

Honorary Curator of the Museum

Casual Vacancies

Vacating Office
28. All Vice Presidents of the Association in office at 4 February 2012...shall hold office for life or until they shall cease to be a member of the Association, though no additional Vice Presidents may be elected after this date. A Vice-President may resign from the office of Vice-President without resigning from membership of the Association.

29. The Honorary Curator of the Museum of shall be appointed by the Principal Executive Committee. He shall be ex officio a member of any Committee, Sub-Committee or Working Group appointed to administer the affairs of the Association's Museum.

30. (A) In the event of the death, resignation or incapacity of any Honorary Officer of the Association, a successor may be elected for the period for which the officer so vacating would have served.

(B) Any Honorary Officer of the Association shall vacate his office if he ceases to be a Member of the Association.

\section{SENIOR STAFF OF THE ASSOCIATION}

31 (A) There shall be a Senior Staff Terms and Conditions Committee

(B) The Senior Staff Terms and Conditions Committee shall consist of:

(1) (1) the Chair of the Principal Executive Committee

(2) (2) the Chair of the Finance Committee

(3) (3) 2 members appointed by the Chair of the Principal Executive Committee, one of whom must be a member of the United Kingdom Council elected from the country councils, and one who must be a member of the Principal Executive Committee

(C) The remit of the Senior Staff Terms and Conditions Committee shall be:

(1) To determine, and review from time to time, the terms and conditions of the Chief Executive, Finance Director, and all senior staff appointed at the Director grade, and to consider recommendations on remuneration from the Finance Committee for all these staff;

(2) To manage the recruitment process for the Chief Executive and Finance Director, and to recommend to the Principal Executive Committee suitable individuals for appointment;

(3) To be responsible for disciplinary procedures in regard to the Chief Executive or Finance Director;

(4) To recommend the removal of the Chief Executive or Finance Director to the Principal Executive Committee

32. The Chief Executive of the Association shall be appointed by the Principal Executive Committee, and 
shall be the most senior member of staff with the responsibility of ensuring the implementation of the strategic and operational objectives set by the Principal Executive Committee. The Chief Executive shall also have responsibility for the financial integrity, operational efficiency and legal compliance of the Association. In discharging these duties the Chief Executive shall be regarded as the most senior adviser to the Principal Executive Committee. The Chief Executive shall be removable by the Principal Executive Committee subject to the terms of any agreement between the Chief Executive and the Association.

33. The Finance Director shall be appointed by the Principal Executive Committee and shall be responsible for financial planning and reporting financial performance to the Principal Executive Committee; providing all necessary advice and support to the Principal Executive Committee in regard to financial planning and performance; managing the financial risks of the organisation; and ensuring the effectiveness of financial control systems. The Finance Director shall be removable by the Principal Executive Committee subject to the terms of any agreement between the Finance Director and the Association.

\section{PRINCIPAL EXECUTIVE COMMITTEE}

34. (A) The overall control and direction of the policy and affairs of the Association shall be vested in a Principal Executive Committee, consisting of 15 members elected in accordance with Articles 35, 36, 37 and 38.

(B) The Principal Executive Committee is the Association's board of directors, and as such it holds all requisite statutory, commercial and common law duties and responsibilities.

(C) The Principal Executive Committee is also the body responsible for the lawful conduct of the Association as a recognised trade union for the purposes of the Trade Union Act 1984 and any amending legislation.

(D) The Principal Executive Committee shall exercise the necessary powers to fulfil its responsibilities within the remit described in Article 34 (B) and (C), and these powers shall include:

- ensuring the legal compliance of the Association in regard to all of its activities

- agreeing the strategy and operational plans of the Association, and setting the Association's annual budget

- holding the Chief Executive and senior management team to account for the progress and implementation of strategic and operational objectives

- the determination of policy

- the management of risk

- ensuring effective financial stewardship of the Association, and holding the Chief Executive and Finance Director to account in regard to the Association's financial planning and financial controls

- borrowing or raising sums of money and to mortgage or charge the undertaking property and assets of the Association or any part thereof and to issue debentures, debenture stock and other securities whether outright or as security for any debt, liability or obligation of the Association

- preparing the Association's accounts for audit and submitting the audited accounts to the Association's Annual General Meeting for approval

- preparing the Association's annual report for submission to the Association's Annual General Meeting for approval

E) The Principal Executive Committee shall also have power to:

- agree the per capita grant payable to branches in accordance with the by - laws 
- to make arrangements for the election of members, the cessation of membership, the compulsory termination of membership, the readmission to membership and the creation of new categories of membership

- to approve changes to Branch/Professional Group boundaries and/or membership

- to receive and consider reports from the country councils, and the standing committees of the Principal Executive Committee

- nominate the President of the Association to the Annual General Meeting, upon the recommendation of the Honours and Awards Committee

- agree such other Honorary Officers provided for by these Articles

- to agree Honorary Life Members for election

- to agree recipients for the Association's honours and awards upon the recommendation of the Honours and Awards Committee

- to agree, upon the recommendation of the Honours and Awards Committee, the bestowing of Honorary Membership of the Association, the Fellowship of the Association, the John Tomes Medal, an entry on the Roll of Distinction, Distinguished Membership, the Certificate of Merit for Services to the Association and the Certificate of Merit for Services to the Association

- to maintain or cause to be maintained proper minutes and records of all meetings of the Principal Executive Committee, and Standing Committees

- to recommend changes to By-Laws to the UK Council

(F) The Principal Executive Committee shall also appoint a scientific adviser for the Association

(G) Nothing done by the Association in General Meeting shall invalidate any prior act of the Principal Executive Committee or any standing committee thereof

35 The Principal Executive Committee shall consist of 15 members. At least two members shall be elected on a UK wide ballot and one member of the Principal Executive Committee shall be returned from Scotland, one member from Wales, and one member from Northern Ireland. Subject to the number of members elected on a UK wide ballot, the remaining members shall be returned from electoral regions in England, as determined in accordance with Article 36.

36 The Representative Body shall devise the electoral system, the number of members elected on a UK wide ballot, the number and identity of the electoral regions in England, and the cycle of elections, to elect the first Principal Executive Committee (the 'Initial Electoral Structure') following the adoption of these Articles. It shall also devise the method of election to be used for the country councils in accordance with Article 56(A) as part of the Initial Electoral Structure.

37 The cycle of elections to the Principal Executive Committee devised by the Representative Body in accordance with Article 36, shall be subject to the provision that no member of the Principal Executive Committee shall serve longer than three years before he is required to seek re election. In order to facilitate the desired electoral cycle, exceptions to this rule may be made in regard to the composition of the first Principal Executive Committee to be elected following the adoption of these Articles, and appointments thereunder may range up to five years.

38. Elections to the Principal Executive Committee in 2012 shall be completed no later than the end of June, in accordance with the Initial Electoral Structure, and a resolution proposing the inclusion of the system 
set out in the Initial Electoral Structure as Articles of Association shall be proposed at the Annual General Meeting of the Association in 2012. In the event that the resolution to adopt the Initial Electoral Structure is not passed at the Annual General Meeting, the Principal Executive Committee shall consult the United Kingdom Council in order to devise an alternative electoral structure (which does not conflict with these Articles or Statute) and the Principal Executive Committee shall present to the following Annual General Meeting the alternative electoral structure proposed by the United Kingdom Council.

\section{PRINCIPAL EXECUTIVE COMMITTEE - DISCLOSURE OF INTEREST}

Disclosure of Interest
39. (A) No member of the Principal Executive Committee shall be disqualified by his office from contracting with the Association, either as vendor, purchaser, or otherwise, nor shall any contract or arrangement entered into by or on behalf of the Principal Executive Committee in which any Member thereof is in any way interested be liable to be avoided, nor shall any Member of the Principal Executive Committee who contracts or is interested in this way be liable, because he is a Member of the Principal Executive Committee to account to the Association for any profit which he may realise from this contract or arrangement, but it shall be the duty of any Member of the Principal Executive Committee who is in any way, whether directly or indirectly, interested in a contract or arrangement or proposed contract or arrangement with the Association or any interest he may have in any company, organisation or association with which the Association may potentially be in competition or in conflict, to declare at the earliest opportunity the nature of his interest in writing to the Chair of the Principal Executive Committee or the Chief Executive.

(B) The said declaration so required to be made shall be considered at a meeting of the Principal Executive Committee at which the question of entering into the contract or arrangement is first taken into consideration, or, if the Member of the Principal Executive Committee was not, at the date of that meeting, interested in the proposed contract or arrangement, then at the next meeting of the Principal Executive Committee held after he became so interested and subsequently on every occasion where the interest is relevant to the Association's discussions. A list of all interests disclosed is to be circulated to all Members of the Principal Executive Committee at the beginning of each year in a triennium.

(C) In a case where the Member of the Principal Executive Committee becomes interested in a contract or arrangement after it is made, the said declaration shall be made at the first meeting of the Principal Executive Committee held after the Member of the Principal Executive Committee became so interested.

(D) For the purposes of this Article, a general notice given to the Members of the Principal Executive Committee by a Member of the Principal Executive Committee that he is a member of a specified company or firm, and is to be regarded as interested in any contract or arrangement which may, after the date of the Notice, be made with the company or firm, shall be deemed to be a sufficient declaration of interest in relation to any contract or arrangement so made.

(E) A Member of the Principal Executive Committee shall not vote in respect of any contract or arrangement in which he is so interested, and if he shall so vote his vote shall not be counted.

(F) Where a contract or arrangement is continuing, a declaration of

interest shall be repeated at the first meeting of the Principal Executive Committee after each triennial election.

(G) If a Member of the Principal Executive Committee is in doubt whether an interest should be declared, he should seek the advice of the Chair of the Principal Executive Committee who will consult with the Chief Executive. Should the Member not agree with the advice given, he may take the matter to the Education and Standards Committee. The Chair of the Principal Executive Committtee, the Chair of any Committee of the Association and the Chief Executive may also take a case to the Education and Standards Committee for advice. In deciding whether or not such a declaration be required regard shall be had to the principles set out in the Nolan Committee Report of 1995 entitled "The First Report on Standards in Public Life". 
(H)If another Member of the Association has reasonable grounds to believe that a relevant interest has not been declared, and a personal approach to the Member concerned has not resolved the matter, he should draw it to the attention of the Chair of the Principal Executive Committee and the Chief Executive who may deal with the case or seek the advice of the Education and Standards Committee. Should the complainant not be satisfied with the outcome, he may go direct to the Education and Standards Committee.

(I) Should a Member not comply with the advice given by the Education and Standards Committee, the Chair of the Principal Executive Committee and the Chief Executive may put a resolution to the Principal Executive Committee that the Member concerned be removed from office as a Member of the Principal Executive Committee and, if considered appropriate, the Association.

(J) These disclosure provisions shall apply equally to any interest which a Member of the Principal Executive Committee may have in any company, organisation or association with which the Association may be in competition or conflict, or may potentially be in competition or conflict (irrespective of whether such a company, organisation or association is in a contractual relationship with the Association), appointments, shareholdings, consultancies and ad hoc projects (paid or unpaid) including positions held within the National Health Service.

(K) These disclosure provisions shall apply mutatis mutandis to any member of the country councils and United Kingdom Council, of any Standing Committee of the Principal Executive Committee or working group.

\section{PRINCIPAL EXECUTIVE COMMITTEE - PROCEEDINGS}

40. (A) The Principal Executive Committee shall elect a Chair from amongst its number for a term of office of three year's duration, in accordance with a procedure administered by the Chief Executive

(B) The member so elected Chair of the Principal Executive Committee may stand for re election for a further three year term, but no member may serve as Chair for more than 2 consecutive three year terms

(C) The member elected Chair of the Principal Executive Committee by June 2012 shall vacate office at the first meeting of the Principal Committee in 2015, and the period between June 2012 and the first meeting of the Principal Executive Committee in 2015 shall count as one term of office for the purposes of Article 40 (B)

41. (A) The Principal Executive Committee shall elect a Deputy Chair from amongst its number for a term of office of three year's duration, in accordance with a procedure administered by the Chief Executive

(B) The member so elected Deputy Chair of the Principal Executive Committee may stand for re election for a further three year term, but no member may serve as Deputy Chair for more than 2 consecutive three year terms

(C) The member elected Deputy Chair of the Principal Executive Committee by June 2012 shall vacate office at the first meeting of the Principal Committee in 2015, and the period between June 2012 and the first meeting of the Principal Executive Committee in 2015 shall count as one term of office for the purposes of Article 41 (B)

42. The Chief Executive will, in regard to the conventions that limited the consecutive terms of office holders in the Executive Board and Representative Body prior to the adoption of these Articles, exercise his discretion in order to ensure that those conventions are applied as far as possible in regard to candidates seeking election to office in the Principal Executive Committee, country councils and United Kingdom Council.

43. (A) The Principal Executive Committee shall meet not less than four times every year and on such other occasions as it shall deem necessary and expedient for the work of the Association

(B) the quorum for a meeting of the Principal Executive Committee shall be 9 members

44. In the event that neither the Chair of the Principal Executive Committee or Deputy is present within 
fifteen minutes from the scheduled start of a meeting of the Principal Executive Committee, or neither is willing or able to act, then those present shall elect from amongst their number a person to be the Chair of the scheduled meeting by simple majority.

Article 45. The Principal Executive Committee may establish such standing committees and/or working groups as the Principal Executive Committee may from time to time determine and each such committee shall have the membership, quorum and the remit as the by - laws may from time to time prescribe. In accordance with the provisions of this Article the Representative Body shall as a minimum establish the following standing committees:

(1) Central Committee for Dental Academic Staff

(2) Central Committee for Hospital Dental Services

(3) General Dental Practice Committee

(4) Northern Ireland Dental Practice Committee

(5) Northern Ireland Salaried Dentists Committee

(6) Salaried Dentists Committee

(7) Scottish Salaried Dentists Committee

(8) Scottish Dental Practice Committee

(9) Students committee

(10) Young Dentists Committee

(11) Wales Committee for Community Dentists

(12) Welsh General Dental Practice Committee

46 (A) There shall be a committee of the Principal Executive Committee called the Audit Committee.

(B) The Audit Committee shall consist of:

(1) A Chair, appointed by the Principal Executive Committee who shall be a member of the Principal Executive Committee and not a member of the Finance Committee, and nor the Chair or Deputy Chair of the Principal Executive Committee

(2) the incumbent Chair of the Audit Committee in June 2012 may be reappointed by the Principal Executive Committee to serve the remainder of a three year term of office even though he may not be a member of the Principal Executive Committee, but thereafter the Chair of the Audit Committee shall be appointed in accordance with Article 50 (B) (1)

(3) Three members appointed by the Principal Executive Committee from its membership

(4) One member appointed on the joint recommendation of the Chair of the Principal Executive Committee and the Chairs of the country councils, who shall not be a member of the Principal Executive Committee or the country councils but who has substantial experience of corporate financial management gained at a senior level 
(5) Each member of the Audit Committee shall be appointed for a three year term of office, and may serve a further consecutive three year term unless otherwise prevented by the provisions of these Articles

(6) The Chair of the Audit Committee shall be appointed for a three year term of office, and may serve a further consecutive three year term of office unless otherwise prevented by the provisions of these Articles

(C) The Audit Committee shall elect a Vice-Chair from its number.

(D) The Audit Committee shall not have the power to co - opt additional or replacement members.

(E) The quorum shall be three members, one of whom will be the Chair or Vice-Chair.

(F) Committee may invite such other observers, consultants or assessors as it considers appropriate to its business from time to time. Such persons shall have the right to speak at meetings of the Audit Committee but not to vote.

(G) The remit of the Audit Committee shall be:

(1) On behalf of the Principal Executive Committee, to carry governance responsibility for matters relating to the auditing of the financial statements, procedures and transactions as set out in the appropriate Statement of Auditing Standards and any other areas of the Association's financial affairs.

(2) To oversee the discharge of the Association's responsibilities, and those of its Principal Executive Committee and of the Association's committees, relating to financial statements, governance, risk management, internal control systems and external audit.

(3) To consider with the Association's external auditors the nature and scope of the audit, to ensure the independence, objectivity and effectiveness of the audit process, to consider the fee of and any questions of rotation, resignation or dismissal of the external auditors and to make recommendations to the Principal Executive Committee and the Annual General Meeting as appropriate.

(4) To review the external auditor's post-audit letter and the management response.

(5) To review the annual financial statements and accompanying reports.

(6) To keep under review the effectiveness of the Association's governance, risk management and internal control systems.

(7) To review reports of internal processes and systems.

(8) To consider such other matters as the Audit Committee and the Principal Executive Committee may from time to time consider appropriate.

(H) The Audit Committee shall report to the Principal Executive Committee in accordance with any regulations that may from time to time be imposed upon it by the Principal Executive Committee

(I) The Audit Committee shall publish each year a report on the discharge of its remit which shall be laid before the Annual General Meeting.

47. The United Kingdom Council shall appoint a Scrutiny Committee which shall have the membership, quorum and the remit as the By - Laws may from to time prescribe. The United Kingdom Council may 
propose changes to the By - Laws concerning the Scrutiny Committee and the Principal Executive Committee shall approve such changes to the By- Laws unless they are inconsistent with these Articles of Association.

Finance Committee

48 (A) The Principal Executive Committee shall, in order to provide for effective scrutiny of financial matters, appoint a Standing Committee of the Principal Executive Committee, to be known as the Finance Committee. Such Committee shall be appointed annually and will comprise:

- the Chair of the Principal Executive Committee,

- four members appointed by the Principal Executive Committee from their membership

and, in addition, the following non-voting members;

- the Chief Executive; and

- the Finance Director

(B) The Finance Committee shall elect a Chair from amongst its number who shall not be the Chair of the Principal Executive Committee.

(C) The Finance Committee will be responsible for:

a) the examination of the Association's annual budget and monthly management accounts

b) the approval of contracts and expenditure as required by the standing financial controls of the Association in force from time to time.

c) recommendations on remuneration matters to the Senior Staff Terms and Conditions Committee

d) ensuring value for money in the Association's activities.

(D) The Finance Committee will report to the Principal Executive Committee in accordance with any regulations that may from time to time be imposed upon it by the Principal Executive Committee and, where necessary, or where requested by the Principal Executive Committee, provide guidance and recommendations to it.

(E) The Finance Committee will refer to the Audit Committee any concerns with regard to accounting or financial control which may require further investigation.

\section{MISCELLANEOUS PROVISIONS}

Validity of acts

Resolutions in writing

Vacation of Office
49 (A) All acts done by any meeting of the Principal Executive Committee or any Standing Committee or Working Group, or by any person acting as a member thereof shall, notwithstanding that it shall afterwards be discovered that there was some defect in the appointment of such persons or that they or any of them were disqualified, be as valid as if every such person had been duly appointed and was qualified to act.

(B) A resolution, in writing, signed by seventy-five per cent of the voting Members of the Principal Executive Committee, or of any Standing Committee or Working Group shall be as valid and effectual as if it had been passed by a meeting equivalent thereof duly called and constituted.

50 (A) The office of a Member of the Principal Executive Committee, or country council or the United Kingdom Council shall be vacated :

(1) If he becomes bankrupt or makes any arrangement or composition with his creditors generally;

(2) If he becomes of unsound mind; 
(3) If by notice in writing to the Association he resigns his office;

(4) If he becomes prohibited from holding office by any Court order made under the Statutes;

(5) If he is removed from office by a resolution duly passed pursuant to the Statutes;

(6) If he ceases to be a member of the Principal Executive Committee, a country council or the United Kingdom Council by virtue of any provision of the Articles.

(B) The office of a member of any other Committee appointed pursuant to these Articles shall be vacated in the events mentioned in sub-paragraphs $50(\mathrm{~A})(1)$ to (5) and also (in case he is a member of the Association) if he ceases from any cause to be a member of the Association.

No disqualification for Age (C) Any person may be appointed or elected as a member of the Principal Executive Committee or any Standing Committee or Working Group whatever his age, and no member shall be required to vacate his office by reason of his attaining or having attained the age of 70 or any other age.

\section{COUNTRY COUNCILS AND UNITED KINGDOM COUNCIL}

51. (A) A country council shall be formed in each country of the United Kingdom, with the following remit:

- To provide regular advice and comment to the Principal Executive Committee as consultative committees

- To consider and advise the Principal Executive Committee on all matters relating to dentistry within the country concerned

- To advise the Principal Executive Committee on all aspects of policy within the country concerned, facilitating external expert and member input to policy formation where required

- To receive regular reports from the Principal Executive Committee, to enable each country council to debate and comment on the activities of the Principal Executive Committee without prejudice to the rights of the membership as a whole

- To liaise with branches and sections

(B) Each country council shall be constituted by members elected from the branches in each country as provided for in Articles 52, 53, 54, and 55. Additional voting and non voting members may be appointed or elected to each country council as determined by or in accordance with the By - Laws.

(C) The formation of the councils in accordance with Articles 51, 52, 53 and 54 shall be completed in 2012 no later than the end of August. The members of the councils shall remain in office until the end of February 2015, following elections and nominations for a reconstituted council. Thereafter each council shall serve a three year term, with a newly reconstituted council in place by the end of February in the year in which the three year term expires. Additional members appointed or elected in accordance with the By Laws shall be appointed and elected, and their terms of office shall expire, in accordance with this electoral cycle (unless their membership is dependent on the nomination or office held in another committee, in accordance with the By- Laws).

(D) Proposals to create, or alter, additional voting and non voting members as provided for in Article 51 (B) may only be submitted by a country council in respect of its own membership, and the Principal Executive Committee shall approve the requisite changes to the By - Laws unless such changes are inconsistent with these Articles of Association.

(E) Each country council shall elect a Chair and Deputy Chair from amongst the members elected from the branches for such term of office as the country council shall detrmine.

(F) There shall normally be four meetings of each country council each year, though fewer or more 
meetings may be convened as each council shall deem necessary and expedient for the work of the Association

52 (A) The English Council shall as a minimum consist of the following voting members: one member elected from each Branch within England. Total membership of the English Council should not be more than 30 members.

(B) Members of the Principal Executive Committee elected from constituencies in England shall also be ex officio and non voting members of the English Council.

53 (A) The Scottish Council shall as a minimum consist of the following voting members: two members elected from each of the three Scottish Branches;

(B) The member of the Principal Executive Committee elected from the constituency of Scotland shall also be an ex officio and non voting member of the Scottish Council.

54. (A) The Welsh Council shall as a minimum consist of the following voting members: 4 members elected by members in the Welsh branches.

(B) The member of the Principal Executive Committee elected from the constituency of Wales shall also be an ex officio and non voting member of the Welsh Council.

55. (A) The Northern Ireland Council shall as a minimum consist of the following voting members: three members elected by the Northern Ireland Branch.

(B) The member of the Principal Executive Committee elected from the constituency of Northern Ireland shall also be an ex officio and non voting member of the Northern Ireland Council.

56. (A) Each branch of the Association shall be entitled to elect members of the country councils in accordance with the provisions in Articles 52 (A), 53 (A), 54 (A).

The method of election to the country councils shall be considered by the Representative Body as part of its responsibility to devise an Initial Electoral Structure in accordance with Article 36.

(B) Candidates for election to the country councils must have been members of the Association for a minimum of six months on the date the Returning Officer invites nominations, and the Returning Officer may at his discretion prescribe a longer minimum period.

(C) Members shall be entitled to vote (except those not entitled to vote as defined in Article 56 (D) in each branch.

(D) students and affiliate members are not entitled to vote or stand for election in country council elections.

(E) Voting papers shall be delivered or sent to each elector by the Returning Officer (appointed by the Chief Executive, who may be the Chief Executive himself). The voting papers shall contain the names of those candidates standing in the elector's constituency, who have been nominated each by three electors on or before an appointed day of which not less than 28 days notice has been given in the Journal.

(F) Provided that if the number of candidates for election in any constituency is of equal to or less than the number of persons to be elected, the use of voting papers shall not be required and such candidate shall be deemed to have been elected unopposed by the Returning Officer.

(G) If any member of a country council shall die or retire or otherwise cease to be a member of a country council before the expiration of his term of office, then the Returning Officer shall organise an election or seek a nomination for a replacement to serve the remainder of the term of office unless the said term of office on the date the replacement could reasonably assume office is 6 months or less 
from its expiration.

57. (A) A United Kingdom Council shall be formed with the following remit:

- To consider all issues of policy and matters affecting dentistry at the United Kingdom level of government.

(B) The United Kingdom Council shall as a minimum consist of the following voting members:

- 16 members elected from the English Council, from amongst the members elected from the branches in England

- 3 members elected from the Scottish Council, from amongst the members elected from the branches in Scotland

- 2 members elected from the Welsh Council, from amongst the members elected from the branches in Wales

- 2 members elected from the Northern Ireland Council, from amongst the members elected from the branch in Northern Ireland

(C) Additional voting and non voting members may be appointed or elected to the UK Council as determined by or in accordance with the By - Laws, subject to a total membership of the United Kingdom Council of 35 members. Any proposals to alter the By Laws to permit more or less additional voting and non voting members may only be submitted with the joint consent of the Chairs of the country councils. The Principal Executive Committee shall approve the requisite changes to the By - laws save to the extent that such changes are not inconsistent with these Articles of Association.

(D) The United Kingdom Council shall be chaired in rotation by each of the Chairs of the country councils, the first sequence of rotations to be determined by agreement or lot.

(E) There shall normally be two meetings of the UK Council each year, though fewer or more meetings may be convened as the UK Council shall deem necessary and expedient for the work of the Association.

(F) A meeting of the United Kingdom Council may be convened, and its business determined, by the joint agreement of the chairs of the country councils. The business of a scheduled meeting in rotation may be determined by the chair for that meeting in consultation with the other chairs.

(G) The Principal Executive Committee shall deliver an annual report on its activities to a meeting of the United Kingdom Council.

(H) The United Kingdom Council shall have the power to convene an Extraordinary General Meeting of the Association, and to determine the agenda for that meeting, subject to the support of a two thirds majority of its voting members.

(I) An Extraordinary General Meeting convened in accordance with the provision in Article 57 (H) )may include a motion to dissolve the Principal Executive Committee, and proceed to elections for a new Principal Executive Committee.

(J) Any members displaced by the dissolution of the Principal Executive Committee shall not be barred from standing for re election unless they are deemed ineligible in accordance with the provisions of these Articles.

Annual Meeting of Members

of Association

58. A General Meeting (hereinafter called an "Annual General Meeting") of the Association shall be held once in every year at such time and place as may from time to time be prescribed by the Association at the preceding Annual General Meeting, and if no time or place is so prescribed at such time and 
place as may be determined by the Principal Executive Committee An Annual General Meeting shall be specified as such in the notices calling it. Not more than fifteen months shall be allowed to elapse between any two Annual General Meetings. All other General Meetings shall be called Extraordinary General Meetings.

Extraordinary Meetings 59. (A) The United Kingdom Council may, whenever they think fit, convene an Extraordinary General Meeting, and extraordinary General Meetings shall also be convened on such requisition or in default may be convened by such requisitions as provided by the Statutes. Provided always that as long as the number of members of the Association representing one-tenth of the total voting rights of all the members who at the date of deposit of a requisition have a right to vote at General Meetings of the Company exceeds 500 the Statutes shall have effect as if the number 500 were substituted for the number of members representing not less than one-tenth of such voting rights.

(B) The following provisions shall have effect in relation to any Extraordinary General Meeting convened on the requisition of members:

(1) The requisition must state the objects of the meeting and must be signed by the requisitionists and deposited at the registered office of the Association, and may consist of several documents in like form each signed by one or more requisitionists.

(2) If the United Kingdom Council does not within twenty-one days from the date of the deposit of the requisition proceed duly to convene an Extraordinary General Meeting the requisitionists, or any of them representing more than one-half of the total voting rights of all of them, may themselves convene an Extraordinary General Meeting, but any meeting so convened shall not be held after the expiration of three months from the said date.

Notices of General Meetings

Chair

Business

Quorum
60. (A) Twenty-one days' notice in writing at the least of every Annual General Meeting and of every meeting convened to pass a special resolution, and fourteen days' notice in writing at the least of every other General Meeting (excluding in every case the day upon which the notice is given or deemed to be given and the day appointed for the meeting) specifying the place, day and hour of the meeting and, in the case of special business, the general nature of the business shall be given in the manner herein authorised to the Auditors and to the Members of the Association.

(B) The accidental omission to send notices of a meeting to or the non-receipt of such notice by any person entitled to receive the same shall not invalidate the proceedings at such meeting.

61. The President of the Association or (failing him) a Vice President, or, if neither of them shall be present within fifteen minutes after the time appointed or if neither of them be willing to act, a Chair appointed by the meeting, shall preside at all General Meetings of the Association.

62. All business that is transacted at an Extraordinary General Meeting and also all business that is transacted at an Annual General Meeting, with the exception of the consideration of the Accounts, Balance Sheets and the ordinary Reports of the Principal Executive Committee, the report of the Auditors and the other routine business of the Association, shall be deemed special business.

63 (A) No business shall be transacted at any General Meeting unless a quorum is present. Save as provided by paragraph (B) of this Article, a quorum at a General Meeting shall be fifty members.

(B) If within one hour from the time appointed for the meeting a quorum be not present, the meeting, if convened upon the requisition of Members, shall be dissolved. In any other case it shall stand adjourned to the same day in the next week at the same time and place, or to such other day and at such other time and place as the Chair may determine, and if at the adjourned meeting a quorum is not present within half an hour from the time appointed for the meeting the members present shall be a quorum. 
Adjournment

Declaration of Chair

64. The Chair may, with the consent of any meeting at which a quorum is present (and shall if so directed by the meeting) adjourn the meeting from time to time, and from place to place, but no business shall be transacted at any adjourned meeting other than the business left unfinished at the meeting from which the adjournment took place. It shall not be necessary to give any notice of adjournment or of the business to be transacted at an adjourned meeting.

65. (A) All questions arising at a General Meeting shall be decided by a show when binding of hands, unless a poll is (before or on the declaration of the result of the show of hand) demanded by:

\section{(1) The Chair, or}

(2) At least five members present and entitled to vote.

(B) Unless a poll is so demanded a declaration by the Chair that a resolution has on a show of hands been carried or lost, or carried by a particular majority, or not carried by a particular majority, and an entry to that effect in the book of the proceedings of the Association shall be sufficient evidence of the fact without proof of the number or proportion of the votes recorded in favour of or against any such resolution.

(C) No poll shall be demanded on the election of a Chair or on a question of adjournment.

(D) The demand for a poll may be withdrawn.

Poll

66. (A) If a poll be demanded in manner aforesaid, the same shall be taken at such time and place and in such manner (with or without the use of voting papers) and either at once or after an interval of adjournment or otherwise, as the Chair directs, and the result of such poll shall be deemed to be the resolution of the Association in General Meeting.

(B) The demand for a poll shall not prevent the continuance of a meeting for the transaction of any business other than the question on which the poll has been demanded.

Votes

67. (A) Every Member shall have one vote and no more, but:

(1) No person who is a Temporary, Affiliate or Student Member shall have a vote, and

(2) No Honorary Member shall have a vote unless he is for the time being entitled to Ordinary Membership of the Association.

(B) No Member shall be entitled to vote at any meeting unless all moneys which at the time of such meeting shall have been due from him to the Association shall have been paid.

(C) No Member shall be entitled to vote by proxy.

Chair's casting vote

Minutes
68. In the case of an equality of votes at any General Meeting, whether on a show of hands or on a poll, the Chair of the meeting at which the show of hands takes place or at which the poll is demanded shall be entitled to a second or casting vote.

69. (A) The Association shall cause minutes of all proceedings of General Meetings of the Association to be entered in books kept for that purpose.

(B) The books containing the minutes of proceedings of General Meetings of the Association shall be kept at the registered office of the Association and shall be open to the inspection of any Member without charge during the normal hours of business.

(C) Any Member shall be entitled to be furnished within seven days after he has made a request in that behalf to the Association with a copy of any such minutes of General Meetings. 


\section{REFERENDUM ON RESOLUTION OF GENERAL MEETING}

Suspense of operation of resolutions pending consideration

Consideration of resolutions by the

Executive Board

Approval of Resolution Referendum to be made

Resolution operative on approval or in default of Referendum

Notice of Suspense

in Journal

Majority of Aggregate Votes to determine results

(F) Where any resolution is thus referred, it shall not be valid and binding as a decision of the Association unless and until it is approved by a majority of the aggregate votes given thereon by Members of the Association. Such votes shall be given by voting papers and the form of the voting papers and the manner in which they are to be filled up and returned by Members shall be prescribed by the Principal Executive Committee.

No referendum in respect of Special or Extraordinary Resolution

(G) The foregoing provisions as to a Referendum shall not apply to a Special Resolution or to an Extraordinary Resolution, or to any Resolution relating solely to the procedure or to any business transaction at an Annual General Meeting which is not special business as defined in Article 66, or to any resolution which under the provisions of the Articles or of the Statutes must be passed by the Association in General Meeting.
(B) If the Principal Executive Committee, at such meeting, is of the opinion that each such resolution properly represents the wishes of the Members of the Association as a whole, it shall take no action in connection with such resolution and the same shall come into operation at the conclusion of the meeting.

(C) The Principal Executive Committee shall determine on a referendum on the ground that a resolution does not properly represent the wishes of the Association.

(D) If the Principal Executive Committee at such meeting approves of any such resolution as aforesaid, or does not determine on a Referendum, the resolution shall come into operation at the conclusion of the meeting.

(E) If at such meeting the Principal Executive Committee determines on a Referendum, the Representative Body shall publish the fact in the earliest practicable issue of the Journal and shall refer the Resolution, accompanied by such observations as the Principal Executive Committee may think desirable, to the consideration of all the Members of the Association in manner hereinafter provided.

THE SEAL

Seal 


\section{BY-LAWS AND AMENDMENTS TO ARTICLES AND BY-LAWS}

By-laws

Committee

\section{ACCOUNTS}

Accounts to be kept

Accounts to be laid before Members
72. (A) The By-laws set forth in the Schedule hereto shall be deemed to be part of these Articles.

(B) The By-laws may from time to time be altered by Special Resolution of the Principal Executive.

(C) Save as so far as determined by Statute or by the Articles the membership and mode of government of the Association, and the rights and obligations of every member or groups of members shall be such as may from time to time be prescribed or determined by or in accordance with the By-laws and the By-laws may from time to time be added to, amended, altered or repealed by the Principal Executive Committee, subject to the provisions hereinbefore contained.
73 (A) The Principal Executive Committee shall cause accounting records to be kept in accordance with the Statutes.

(B) The accounting records shall be kept at the registered office of the Association or (subject to the Statutes) at such other place or places as the Principal Executive Committee think fit, and they shall at all times be open to the inspection of the Members of the Principal Executive Committee.

74. (A) At the Annual General Meeting in every year there shall be laid before the Association a proper income and expenditure account for the period since the last preceding account made up to date not more than ten months before such meeting (as required by Statute), together with a proper balance sheet made up as at the same date.

(B) Every such balance sheet shall be accompanied by proper reports of the Principal Executive Committee and the Auditors, and copies of such account, balance sheet and reports (all of which shall be framed in accordance with any statutory requirements for the time being in force) and of any other documents required by law to be annexed or attached thereto or to accompany the same shall not less than twenty-one clear days before the date of the meeting, subject nevertheless to the provisions of the Statutes, be sent to the Auditors and to all other persons entitled to receive notices of General Meetings in the manner in which notices are hereinafter directed to be served. The Auditors' report shall be open to inspection and read before the meeting as required by the Statutes.

(C) Auditors shall be appointed and their duties regulated in accordance with the Statutes.

\section{NOTICES}

Service of Notices on Members

Service of Notices on Branches, Sections or Professional Groups

Service by post
75. A Notice may be served by the Association upon any Member either personally or by sending it through the post in a prepaid letter addressed to such Member at his registered address or by publication of such notice in the Journal and sending a copy of the Journal containing such notice to such Member prepaid and addressed as aforesaid. For the purposes of this Article the registered address of a Member shall be the address appearing as his in the List of Members of the Association for the time being.

76. A notice may be served by the Association on any Branch, Section or Professional Group by serving the same as aforesaid on the secretary of such Branch, Section or Professional Group, and if there be none then upon any two Members of the Executive Board or other Governing Body of such Branch, Section or Professional Group.

77. Any notice if served by post shall be deemed to have been served on the fourth day following that on which the letter or copy of the Journal containing the same is posted, and in proving such service it shall 
be sufficient to prove that the letter or copy of the Journal containing the notice was properly addressed and put into the post office as a prepaid letter.

Indemnity

\section{WINDING UP

Winding up
78. (A) Every member of the Principal Executive Committee, and of every other Committee appointed under the Articles, every Honorary Officer and every other Officer or servant of the Association shall be entitled to be indemnified out of the assets of the Association against all losses or liabilities which he may sustain or incur in or about the execution of the duties of his office or otherwise in relation thereto, including any liability incurred by him in defending any proceedings, whether civil or criminal, in which judgement is given in his favour or in which he is acquitted or in connection with any application under the Statutes in which relief is granted to him by the Court and no such member, officer or servant shall be liable for any loss, damage or misfortune which may happen to or be incurred by the Association in the execution of the duties of his office or in relation thereto. But this Article shall only have effect insofar as its provisions are not avoided by the Statutes.

(B) The Principal Executive Committee may pay out of the funds of the Association such sums as it shall from time to time determine to be reasonable in respect of travelling, hotel and other expenses and loss of remunerative time incurred by any member of the Association (whether or not an Honorary Officer or a member of the Principal Executive Committee or of any Committee) or any other person in attending any meeting or otherwise rendering service to the Association. 